Institute for Research on Poverty Discussion Paper no. 1093-96

Welfare Policy:

The Administrative Frontier

\author{
Lawrence M. Mead \\ Department of Politics \\ New York University
}

July 1996

IRP publications (discussion papers, special reports, and the newsletter Focus) are now available electronically. The IRP Web Site can be accessed at the following address:

http://www.ssc.wisc.edu/irp. 


\begin{abstract}
The process of national welfare reform has been overtaken by local reform as states implement experimental programs under federal waivers. Most of these initiatives attempt to enforce work or otherwise control the lives of the dependent in return for support. Research, which traditionally stressed the social and economic aspects of welfare or poverty, must be reoriented to address the administrative issues raised by the emerging paternalism. A combination of field interviewing and analyses of reporting data can track implementation and connect program operations to outcomes. Such research assesses program performance less surely than experimental trials do but is more useful to operators and more relevant to current program goals. The frontiers of welfare research, like welfare policy, are institutional.
\end{abstract}




\section{Welfare Policy: \\ The Administrative Frontier}

\section{INTRODUCTION}

Below, I first describe the policy context for welfare that has emerged in the last decade from both federal and local initiatives. "Welfare" here primarily means Aid to Families with Dependent Children (AFDC), the principal federal-state family assistance program. I then contrast the usual assumptions made about welfare and its reform in the earlier era with those that prevail now. An emphasis on economics and entitlement has ceded to efforts to control the lifestyle of the adult recipients. I then argue that the approaches researchers take to welfare must also change if they are to address the issues raised by this paternalistic style of reform. Research must focus more on administration, less on the economics of welfare. One resource could be research based on administrative data. I illustrate with the case of Wisconsin. Today's welfare reform is an exercise not in economic transfers, but in state building.

\section{THE POLICY CONTEXT}

Welfare became a critical national issue due to the rapid growth in welfare dependency in the 1960s. The AFDC rolls grew from around 5 million to over 11 million people between the late 1960s and the early 1970s, a period remembered as the welfare boom. The causes included higher benefit levels set by states (which qualified more families for aid), Supreme Court decisions that eliminated some regulatory barriers to aid (such as residency requirements), and above all a greater willingness by those eligible for aid to claim it, due to a decline in welfare stigma.

In response, most states stopped raising benefits as fast as inflation, causing grants to decline in real terms. The fall was offset by increases in Food Stamps and other in-kind benefits, but the value of AFDC and Food Stamps together in the median state still fell 27 percent between 1972 and 1993. Yet 
despite lower benefits, between 1989 and 1993 the rolls surged again, from 11 to over 14 million

persons (U.S. House of Representatives 1994, pp. 374, 395). This time the main causes apparently were a recessionary economy and rising rates of unwed pregnancy (Congressional Budget Office 1993).

\section{$\underline{\text { National Welfare Reform }}$}

The politics of welfare are complicated, and this has prevented government from addressing the welfare problem with large changes in the scale of assistance. One might take growing dependency as a sign of undeserved economic distress and seek to expand aid as an antipoverty device. But liberal proposals to do this in the 1960s and 1970s were defeated because voters and politicians would not accept greater dependency by working-aged adults, and on cost grounds. One might also cut benefits radically or abolish aid in order to force dependent adults to show more self-reliance, but the public has also opposed this out of concern that needy children would be harmed.

Instead, Congress has tried to reform welfare from within by removing its perceived "abuses." From the 1970s, it required states, who run AFDC using federal and state funds, to purge ineligibles from the rolls and reduce grant overpayments ("quality control"), and collect more child support from the fathers of welfare families. Above all, it tried to move more welfare adults into jobs through employment programs linked to AFDC. The latest of these is the Job Opportunities and Basic Skills Training Program (JOBS), set up under the Family Support Act (FSA) of 1988, the last federal welfare legislation.

Recent proposals in Washington continue this tradition of national, mostly work-oriented reform. The Clinton administration proposed in 1994 to require all employable adults to work after two years on the rolls. The Republican Congress proposed in 1995 to require half of all welfare adults to work by 2002, limit families to five years on the rolls, and block-grant welfare to the states so that federal funding would no longer be open-ended. At this writing, Clinton and Congress have not agreed on a bill, and there may be no further federal reform until after the 1996 election. 


\section{The States Reform}

That has not stopped change, however, because a parallel track of reform has broken out at the local level, as Michael Wiseman emphasizes (forthcoming). Going back to the 1970s, some states obtained waivers of normal federal rules to try out welfare reforms of their own. Their authority to do this was expanded by Congress in 1981, and since then presidents have granted waivers liberally. Since the early 1990s, these state proposals have become more numerous and ambitious. Today, further national reform may be stymied, but two-thirds of the states already have waivers to run experimental programs of some kind using AFDC funds (Noble 1996).

Joseph Califano famously remarked that welfare reform is "the Middle East of domestic politics" (Califano 1981, p. 321). The subject arouses such passions on all sides that fundamental change can seem impossible. For several reasons, change is currently easier in state than in national politics. States face more fiscal pressure to reduce dependency than does Washington, because constitutionally they have to balance their budgets as the federal government does not. They also may feel more accountable for welfare and thus more exposed to public upset at the growing rolls than federal officeholders. Governors see the political rewards of reforming welfare, and under current law they already have more control of the program than Washington does. Thus, a Tommy Thompson in Wisconsin or a John Engler in Michigan can make a record against welfare as presidents cannot.

Wisconsin's AFDC rolls have fallen by a third since Thompson became governor in 1987, and this has probably given him more influence on national welfare policy than anyone else. 


\section{THE OLD WELFARE AND THE NEW}

Taken together, the Family Support Act and local reforms shifted the assumptions behind welfare. Until the debates in the mid-1980s that led to FSA, most experts and many policymakers viewed welfare in terms of economics and entitlement. The main purpose of AFDC was income maintenance, to tide one-parent families over their loss of a breadwinner. Welfare was an entitlement in the budgetary sense that benefits were assured to all eligibles. It was also an entitlement in the behavioral sense that welfare adults generally did not have to do anything to get aid except establish and maintain their income eligibility. The goal of welfare administration was mainly to pay out grants accurately.

Welfare reform was largely Washington-led, with most proposals for change stemming from the White House. While quality control and child support reforms were restrictive, other changes were client-oriented. Although reformers aspired to reduce the welfare rolls, they approached that goal mostly by improving the chances recipients had to work, so that more would take jobs. Their tools were again economic_changes in benefits and incentives. In the 1960s and 1970s, clients who went to work were allowed to keep more of their grants, to create "work incentives," and welfare work programs were supposed to train recipients for higher-paying positions, so that they would be more likely to leave welfare. Some liberal reform plans proposed to create government jobs for people who could not find regular employment, a feature also of the recent Clinton plan.

\section{$\underline{\text { Toward Paternalism }}$}

Since FSA and the local reforms, however, welfare has become more paternalist. The goal is not only to support families in need but also to change behaviors by some recipients-especially unwed pregnancy, nonwork, and nonattendance at school—that seem to perpetuate dependency. And whereas the old welfare assumed entitlement, the new rests on an idea of "social contract" or reciprocity: Adult 
recipients are now to be required to work or satisfy other requirements, in addition to financial eligibility rules, in order to get aid. The paternalist trend reflects rising public impatience with welfare, but also a policy history where benefits or training provided to the dependent on a voluntary basis did little to cause more recipients to work (Mead 1986, 1992).

Reform has become more society-oriented. The goal of reducing the caseload is now paramount, with economic gains for the recipients secondary. Reformers seek not only to reduce dependency, but also to send a message to the society that parents are to be held responsible for supporting their families. The style of reform is also less economic. To be sure, conservative reformers at both the national and local level aim to save money, and some states have reduced benefits and eligibility for aid. But severe cuts have so far been imposed only on general assistance, a local program that serves mainly single men, who have the weakest claim to aid. GA also draws no federal funds and thus is largely outside the national welfare debate.

In family welfare, which supports children, curbing access to aid would affront the public desire to protect children, so benefit cuts have so far been small. Most AFDC reform plans seek not to forbid aid, but to use it to change the behavior of welfare parents. Some states have increased work incentives. Some now reward welfare parents financially for marrying (Wisconsin's "Bridefare") or penalize them for having additional children while on welfare (New Jersey's “family cap”). Unfortunately, research and experience suggest that incentives or services that leave the desired actions optional have little influence on the behavior of most recipients. The work incentives provided in federal law in the 1960s and 1970s did not raise work levels on welfare (Moffitt 1992b, pp. 15-19, 40-42), and voluntary training programs and government jobs do not raise earnings enough to take many people off the welfare rolls (Bassi and Ashenfelter 1986). 


\section{The Vogue for Enforcement}

Accordingly, most of the recent reform programs rely on administrative suasions rather than benefits or incentives. Rather than reward a client incrementally for the desired behavior, they make it a precondition for obtaining aid. This trend toward enforcement goes back to the 1980s, when most of the experimental programs implemented by states involved tougher work requirements than were then permitted under federal law. Most of these programs mandated participation. Some of the experiments received better evaluations (mostly by the Manpower Demonstration Research Corporation [MDRC]) than earlier training efforts, and most of the results showed positive impacts on clients' earnings, employment, and dependency (Gueron and Pauly 1991).

In finished MDRC evaluations of AFDC work programs to date, the average gain in earnings was 16 percent and the average cut in dependency was 6 percent, relative to the control group. Those effects are still limited, but they are in general stronger than those recorded by voluntary programs. The main reason probably is that mandatory programs are able to reach a more disadvantaged clientele, one that would not participate on its own. The chance to improve outcomes relative to a control group is thus larger than it would be with the more employable (Friedlander 1988).

The programs' effects on behavior, furthermore, far exceed their economic impacts. The projects evaluated by MDRC typically doubled the share of clients who were active in some work or training activity compared to controls. The vast majority of clients either had to participate in some way, go to work, leave welfare, or accept a sanction (a lower grant) for failing to participate (Mead, forthcoming). This satisfied the public will to hold welfare adults accountable, which is stronger than the will simply to get them off welfare (Mead 1992, pp. 57-63).

Alongside the social contract rationale, MDRC's results were a major force behind the Family Support Act, whose main purpose was to expand welfare employment programs (Wiseman 1991; Mead 1992, chap. 9). FSA did not require that the new JOBS program be mandatory, but it set higher 
participation standards than previously, and most states could not meet these without enforcing participation. By 1995, states were required to have 20 percent of their employable recipients active in JOBS on a monthly basis, a level that sounds low but was much higher than earlier. The recent Clinton and Republican reform plans would both raise that participation rate to 50 percent, although the GOP defines a much larger pool of eligibles than Clinton.

The main theme of the recent waiver programs is an attempt to extend behavioral requirements into new areas, rather than to make economic changes such as benefit cuts or incentives. Of the thirtyfive states that currently have waivers, seventeen have curbed benefits with time limits or family caps, but fourteen require welfare mothers to cooperate in finding the father for child support purposes and twenty have instituted "learnfare," a mandate that mothers stay in school or keep their children in school on pain of a grant reduction. Another popular demand is that mothers immunize their children against disease. The waiver requests now pending assure that the vast majority of states will soon be trying to manage the lives of recipients in some way (Preston 1996; Besharov and Gardiner 1996, pp. $82-83)$.

Such attempts are not new. Welfare is centuries old, as are controversies about whether the recipients are "deserving." Government typically prefers to regiment clients' behavior rather than address the social deficiencies, such as unemployment or low wages, that help to keep people needy (Katz 1986). But the new paternalism really is novel in two ways. First, it is much more visible politically. Past efforts at social control occurred largely prior to the 1960 s welfare boom or in the South, where caseworkers on their own authority often demanded that single mothers stop consorting with men as a condition of aid. Today, welfare is a major issue in national and state politics, and reform occurs through highly visible executive proposals and legislative enactments. Second, the new paternalism has an analytic basis that earlier social control lacked. Positive evaluations have made enforcement of work, if not other behaviors, into a proven device. 


\section{REORIENTING RESEARCH}

The rise of paternalistic welfare raises different issues from those welfare experts and analysts have typically studied. Academic research on welfare or poverty focuses chiefly on economic and social conditions, not the administrative strategies states are now counting on to reduce dependency."

\section{Current Research}

In the main, existing research is descriptive rather than policy-oriented. Studies document the features of various poor or welfare-dependent populations, usually using quantitative databases such as the Current Population Survey (CPS), the Panel Study of Income Dynamics (PSID), or the National Longitudinal Study of Youth (NLSY). Researchers detail, for example, the demographics, family background, or earnings of welfare mothers, low-skilled men, or school dropouts. They find that these groups are more disadvantaged-more nonwhite, less educated — than the mainstream population. They trace these conditions in turn to disadvantaged parents or an earlier life of unwed pregnancy, school failure, or crime. Welfare mothers, for example, are more likely to have grown up on welfare and have children young and out of wedlock than are single mothers who avoid welfare. ${ }^{1}$

But to catalog disadvantage has few policy implications. It does not establish whether or how change is possible. One may infer from the deprivations that the poor or dependent could use higher income or better health or child care. But benefits received are usually the only aspect of social programs that academic research discusses. That is partly because benefits are usually the only thing that the databases record about program participation. They usually do not record the administrative

*The following discussion relies largely on Mead 1994.

${ }^{1}$ Typical compendiums of research along these lines include Jencks and Peterson (1991) and Danziger, Sandefur, and Weinberg (1994). 
suasions that recipients may be under, such as child support orders or work tests, although a few studies add such indicators to academic databases (as, for example, in Plotnick 1990).

The evaluation literature, such as the MDRC studies, shows programmatic effects, but again, policy implications are unclear. These studies contrast outcomes, such as earnings, for clients given a tested program with outcomes for a control group. Random assignment between the two groups obviates selection effects, or unmeasured differences among clients, and thus makes the difference in results a valid estimate of program impact. But this same methodology usually prevents saying much about how the impact was produced. The programs tested are typically complex, with some clients assigned to one activity and some another. Yet the experiment cannot compare the subtreatments for results except in the few cases where clients were randomly assigned among those options. Without randomization, selection effects rather than the alternative treatments might cause the different results. So the trials usually test only the program as a whole, which remains a "black box." One cannot tell what feature of it produced the impact—was it enforced participation, job search, generous support services, or what?

Also, each experiment is discrete. Each permits a valid impact estimate at that site, because randomization and a common labor market take out of the picture nonprogram factors that might affect results. But across sites, social and economic differences are unavoidable, and one cannot tell what role they played in the different success of the programs tested. As a result, comparisons across sites are judgmental at best. MDRC is highly cautious about saying whether or how one local program is "better" than another, even within the same evaluation (Riccio, Friedlander, and Freedman 1994, chap. 8).

The need for rigorous evaluations also recedes the more of them are done. Although evaluations are difficult to collate, results to date make fairly clear that mandatory welfare work programs generally outperform voluntary ones, and that programs that stress work in available jobs 
outperform those that stress preparing clients for better-paying jobs before going to work. ${ }^{2}$ In

Washington, both the Clinton and Republican reform plans mandated participation, and both cut back training in preference to immediate work. Most recent state-level proposals do the same.

\section{$\underline{\text { Administrative Questions }}$}

Far more urgent now are the issues raised by the paternalism attempted by local welfare reforms. One question is implementation in the grossest sense. Is it possible to control the lives of recipients in return for aid, as most of the current reform programs promise?

Many governors today announce welfare reform plans. To do this reaps immediate political rewards, yet few states manage to reduce their rolls by much. Little research exists on the local implementation of reform, but clearly not all proposals are approved by legislatures or obtain waivers, and few are implemented so as to change how welfare runs at the operating level. In New Jersey, for example, Governor Christine Todd Whitman recently proposed to limit families to five years on the rolls and move more recipients into jobs, as against long-term training (Preston 1996). But in 1987, the state enacted a previous reform that was supposed to mandate participation and serve the whole caseload. The bureaucracy resisted the participation requirement, counties proved uncontrollable from the center, funding was inadequate, and little was achieved (Nathan 1993, pp. 4-6, 46-49, 55, 61-67). Similar political and bureaucratic obstacles exist in other states (Norris and Thompson 1995). The Wisconsin experience, where reforms were approved and executed and the rolls fell, is unusual (Mead 1995, 1996).

${ }^{2}$ Tightly run, work-oriented Riverside outperformed most other counties in MDRC's evaluation of California's GAIN program, and in its national JOBS evaluation, programs emphasizing immediate employment have outperformed those stressing education or training for "better" jobs, at least in early results. See Riccio, Friedlander, and Freedman (1994) and Freedman and Friedlander (1995). For the argument that remediation may have long-term benefits, see Friedlander and Burtless (1995). 
The best-known research on reform implementation is process-oriented. The MDRC studies document the flow of clients through programs. They establish that it is possible to implement work programs so as to reach the bulk of the adult caseload, although at best a majority of them will participate actively at any given time (Gueron and Pauly 1991, pp. 128-40). Other studies describe the local politics of reform or the choices states made about services and funding to implement JOBS or other programs (Hagen and Lurie 1994; Norris and Thompson 1995). However, this work and the MDRC process analyses make no connection between program operations and performance. In the MDRC case, the reason again is the methodological inability to connect subprocesses to impacts. Without a bottom line, it is unclear what difference implementation makes.

Even if reforms can be implemented, what is the best way to do so? The answer might come from more sophisticated experimental studies where there is randomization across the ways clients are assigned so that the effects of these can be measured. MDRC is currently performing an evaluation in which competing versions of JOBS are being compared experimentally in three locations (Freedman and Friedlander 1995). It is possible to imagine a very sophisticated experiment in which several variations of a program were tested at several sites while the impact of the entire program was also estimated (Greenberg, Meyer, and Wiseman 1993).

But the logistical problems would be prohibitive. Not only do local program operators resist randomized trials, which force them not to serve all eligibles, but the governors now launching reform programs have made little provision for serious evaluation. In theory, Washington insists that the new programs provide for evaluation before it grants waivers, but the research designs accepted are often compromised. Few of the initiatives launched by Tommy Thompson in Wisconsin have received a definitive assessment (Pawasarat and Quinn 1993). Even if the states cooperated, many of the new programs are too complex to be easily evaluated. Even if an impact were shown, one would not know which facet of the new policy produced it (Wiseman 1993). 


\section{ADMINISTRATIVE RESEARCH}

The nature of the issues and the constraints on experimentation point toward the use of administrative data as a basis for studying the new programs. The databases used to administer welfare grants and JOBS programs are improving in sophistication. Many now cover both the financial and employment aspects of a case, some permit tracking clients over time, and some can provide a fair number of control variables, albeit fewer than in academic databases. There is currently much interest in developing state administrative data as a basis for research, particularly if federal data sources are reduced due to funding cuts. ${ }^{3}$

\section{$\underline{\text { Interviews and Reporting }}$}

The best way to use such data is not to analyze it separate from government operations, as academic databases are used. Rather, use it in conjunction with field research. Interview welfare or work program staff about how they run JOBS or some experimental program, then check this against reporting data on how clients are actually assigned. Interviews provide essential information about the meaning and interpretation of the data, while the reporting in turn is a check on the inevitable subjectivity of interviews.

In a recent study of JOBS in Wisconsin, for example, personnel in Kenosha and Sheboygan counties told me they had a much tougher, work-oriented program than did similar officials in Dane, Fond du Lac, Milwaukee, and Racine counties. Kenosha and Sheboygan said they enforced participation stringently and required clients to work or look for work before going into education or

${ }^{3}$ Projects to do this are underway at the University of California at Berkeley and the University of Wisconsin at Madison. The U.S. Department of Health and Human Services recently commissioned a study of state data (Marcotte 1994), and the subject was intensively discussed at a conference on monitoring the new federalism held by the National Center for Children in Poverty and the Institute for Research on Poverty in Washington, D.C., on February 26, 1996. 
training. The other four counties seemed more lenient about nonparticipation, and they favored training clients for "better" jobs rather than requiring them to take low-wage positions immediately.

I then verified these impressions using reporting data. Table 1 shows the percentage of welfare recipients mandatory for JOBS who were in various statuses in the program in these counties and statewide in a typical month in 1993.

As the interviews suggested, Kenosha and Sheboygan did enforce participation (enrolled) higher proportions of their clients than did the other four counties. They also had much higher percentages in job search and working in regular or unpaid jobs. They were, however, also higher than the other four counties in percentages in education and training, in part because their higher enrollments gave them more people to assign (Mead 1995, pp. 18-22).

In 1994 and 1995, according to state officials, statewide policies required all counties to move toward the tightly run, work-first approach of Kenosha and Sheboygan. The impact of these measures again shows up in the reporting. Between October 1993 and two years later, the share of JOBS clients who were inactive or in education or training statewide dropped from the figures above, while the shares in job search and work rose. The proportions who were enrolled and from disadvantaged groups,

however, fell, a sign that, facing pressure to make job placements, JOBS may be starting to "cream," or serve the more employable (Mead 1996, pp. 18-22).

\section{$\underline{\text { Structural Models }}$}

One can also use administrative reporting to help explain measures of program outcomes, controlling as well as possible for nonprogram influences such as the demographics of clients or the labor market. Typically, the units of analysis are local offices or other subunits of the same program. Outcome measures include the shares of clients getting jobs, working while on welfare, or leaving welfare, plus the quality of their jobs (retention rate, job entry wage). 


\section{TABLE 1}

Percentage of Clients in Administrative Statuses in JOBS, October 1993

\begin{tabular}{|c|c|c|c|c|c|c|c|c|}
\hline & Enrolled & $\begin{array}{c}\text { In Inactive } \\
\text { Statuses } \\
\end{array}$ & Sanctioned & $\begin{array}{c}\text { In } \\
\text { Job Search } \\
\end{array}$ & $\begin{array}{c}\text { In } \\
\text { Regular Jobs } \\
\end{array}$ & $\begin{array}{c}\text { In } \\
\text { Unpaid Jobs } \\
\end{array}$ & $\begin{array}{c}\text { In } \\
\text { Remedial Education } \\
\end{array}$ & $\begin{array}{c}\text { In } \\
\text { Postsec. Education } \\
\end{array}$ \\
\hline Kenosha & 88 & 24 & 1 & 8 & 37 & 3 & 11 & 12 \\
\hline Sheboygan & 90 & 11 & 1 & 8 & 35 & 5 & 32 & 11 \\
\hline Dane & 76 & 34 & 4 & 2 & 16 & 1 & 6 & 8 \\
\hline Fond du Lac & 84 & 33 & 1 & 1 & 24 & 3 & 13 & 9 \\
\hline Milwaukee & 86 & 32 & 8 & 4 & 19 & 1 & 4 & 5 \\
\hline Racine & 78 & 16 & 8 & 3 & 18 & 0 & 8 & 15 \\
\hline Statewide & 86 & 30 & 5 & 4 & 22 & 1 & 7 & 9 \\
\hline
\end{tabular}

Source: Wisconsin Department of Health and Social Services. 
Table 2 shows one such model estimated for the 72 Wisconsin county JOBS programs in 1993. The dependent term is the percentage of JOBS clients who entered jobs expected to last 30 days in that year. The possible explainers included several features of the caseload and the local labor market. Besides an intercept, only the indicated terms were significant at .10 or better.

Results show that the proportions of clients enrolled in JOBS and assigned to job-readiness activities (motivation and job-search coaching) had strong positive effects on the proportions entering jobs, even controlling for the nonprogram environment. The share of the caseload black was the only demographic term to matter, and the growth in employment was the only labor market term (why it is negative is unclear). Similar models for the shares of clients working while on welfare or leaving welfare also showed that the more clients were obligated to participate and to work, the better a county performed. Models for job retention rates and wages were much weaker. In these instances the demographics of the caseload and its education or training mattered more, although administrative terms still showed some influence (Mead 1995, pp. 27-33). ${ }^{4}$

One can build similar models to explain not program performance, but the change in the welfare caseload over time. Modeling across different jurisdictions may be a more valid way to explain caseload change than time-series models. ${ }^{5}$ In Wisconsin, the welfare rolls fell more during the years 1986-94 in counties that enforced work and child support well, controlling for several other demographic and labor market differences. These analyses suggest that Wisconsin's unusual welfare fall is due to both successful reform programs and a favorable economy (Mead 1996). ${ }^{6}$

${ }^{4}$ Several other studies like this exist; a bibliography is available on request. Two examples using the Work Incentive Program, the predecessor of JOBS, include Mitchell, Chadwin, and Nightingale (1980) and Mead (1988).

${ }^{5}$ Time-series models cannot validly explain a dependent term, such as raw caseload levels, that may change without "stationarity." See Chinn (1991).

${ }^{6}$ Michael Wiseman's conclusion (forthcoming) is similar, although I see less evidence that a fall in benefit levels has contributed to the Wisconsin fall. 
TABLE 2

Regression Model of Percentage of JOBS Clients Entering JOBS, Wisconsin Counties, 1993

\begin{tabular}{lccc}
\hline & Coefficient & S.E. & Signif. \\
\hline & & & \\
Percentage of clients enrolled in JOBS & .274 & .096 & .006 \\
Percentage of clients in job readiness activities & .296 & .062 & .000 \\
Percentage of clients black & -.361 & .102 & .001 \\
Percentage growth in employment & -.382 & .204 & .066 \\
Population density & .004 & .002 & .053 \\
Proportion of variation explained $\left(\mathrm{R}^{2}\right)$ & .54 & & \\
\hline
\end{tabular}

Source: Wisconsin Department of Health and Social Services.

Note: Precise variable definitions are available on request. 
Such results suggest that the potential of JOBS to influence welfare is real. Whether welfare recipients go to work is not dictated by the environment, as the descriptive literature on welfare and poverty tends to suggest. It also depends on whether the adults are expected to work. Equally important, structural modeling like this addresses the "how." It breaks into the black box of the program as experimental evaluations seldom can. It shows the payoffs to treating clients one way versus another. Administrative findings reveal the levers that produce results, and they show operators what works best in their context. Such models also permit more rigorous comparisons across local programs than is possible with discrete experimental evaluations. They show which localities perform well or poorly relative to their environment, and something about why.

\section{ADMINISTRATIVE RESEARCH VERSUS EVALUATION}

Of course, this method neutralizes nonprogram influences using statistical controls, in place of the experimental control used in randomized evaluations. That opens the door to selection bias. One cannot be sure that the effect that a particular assignment appears to have is not partly due to unmeasured features of the clients put in that assignment, particularly when the available control terms are limited. It is reassuring, however, that the main implications of structural modeling run parallel to those of the evaluation literature: mandatory, work-focused programs are best. Another problem is identification-establishing that the apparent link between assignment and outcome is causal and in the direction assumed. A safeguard here is field research. Interviews help to establish causal connections and directions. Operators tell you what they think produces results in a program, and this furnishes hypotheses to be verified with the statistical analyses.

Despite these limitations, administrative research can fill a middle in the existing literature. It does not describe the poor or welfare dependent as thoroughly as studies based on academic databases, nor does it provide as sure a measure of program results as the evaluation literature. But it makes a 
firmer connection between policy and outcomes than either of them. Once evaluations have made clear what successful welfare reform programs look like, further evaluations contribute little to policy knowledge. The research agenda should shift to implementation.

A major reason social programs show small effects is incomplete implementation. When implementation is thorough, it will probably be clear that some reform programs do have effects, at least on behavior. Wisconsin not only enforces work on the rolls but diverts many people who are eligible away from welfare by persuading them to take jobs or rely on their families (Mead 1996, pp. 13-18, 38-41). Probably any state that executes such policies as fully will drive many of its employable cases off the rolls, as Wisconsin has done.

In these cases the leading evaluation question is no longer whether a program has any effects on its clients but rather the effects on the larger society. Welfare employment programs may reduce welfare as much or more by deterring entry to the rolls as they do by promoting exit (Moffitt 1996). Such systemic effects fall largely outside welfare or work programs, so they cannot be studied with program-centered evaluations. Experiments cannot reveal what happens to people diverted from welfare by work policies, or who never apply because of them. Other methods such as surveys or the comparison of whole jurisdictions will be needed (Moffitt 1992a; Garfinkel, Manski, and Michalopoulos 1992). ${ }^{7}$

\section{$\underline{\text { State Building }}$}

Administrative assessment also fits the actual goals of the current reforms better than conventional evaluation. Most localities are trying to control client lifestyle, not just to raise employment or reduce dependency, but as an end in itself. The public wants to see welfare parents working and their children in school even if there are no economic improvements-even if enforcing

${ }^{7}$ One study of welfare cuts based partly on a survey is Danziger and Kossoudji (1994-95), but it applies to general assistance rather than AFDC. 
these behaviors costs more than just paying out aid (Mead 1992, pp. 57-63). Like law enforcement or public schools, welfare reform is justified by social values where the concern is more to shape behavior than raise incomes or save money. Implementation, therefore, is a better measure of success than monetary gains for the clients or the government budget.

The caseload decline in Wisconsin has saved millions of dollars. But the state has also invested much of the savings in the support services needed to put recipients to work, especially child care. Even more, it has invested in the bureaucracy, spending millions on the case managers and computerized reporting systems needed to oversee the caseload. The result has been less a cut in welfare than a transformation of the welfare system. Welfare is changing from a subsidy into a regime (Mead 1996, pp. 48-53). The gains are chiefly in the civility of welfare, and are not measurable in dollars and cents. The emerging paternalism is justified by antigovernment rhetoric, but its real agenda is state building. State and local administrators are striving to get control of their caseloads. They are building a welfare state that is able to govern as well as support people. Policy research can help determine the best way to do that. The frontiers of welfare research, like welfare policy, are institutional. 


\section{References}

Bassi, Laurie J., and Orley Ashenfelter. 1986. "The Effect of Direct Job Creation and Training Programs on Low-Skilled Workers." In Sheldon H. Danziger and Daniel H. Weinberg, eds., Fighting Poverty: What Works and What Doesn't. Cambridge: Harvard University Press.

Besharov, Douglas J., and Karen N. Gardiner. 1996. "Paternalism and Welfare Reform." The Public Interest no. 122: 70-84.

Califano, Joseph A., Jr. 1981. Governing America: An Insider's Report from the White House and the Cabinet. New York: Simon and Schuster.

Chinn, Menzie David. 1991. "Beware of Econometricians Bearing Estimates: Policy Analysis in a 'Unit Root' World.” Journal of Policy Analysis and Management 10: 546-67.

Congressional Budget Office. 1993. "Forecasting AFDC Caseloads, with an Emphasis on Economic Factors.” Washington, D.C.: Congressional Budget Office.

Danziger, Sandra K., and Sherrie A. Kossoudji. 1994-95. "What Happened to General Assistance Recipients in Michigan?" Focus 16, no. 2: 32-34.

Danziger, Sheldon H., Gary D. Sandefur, and Daniel H. Weinberg, eds. 1994. Confronting Poverty: Prescriptions for Change. New York: Russell Sage Foundation, and Cambridge: Harvard University Press.

Freedman, Stephen, and Daniel Friedlander. 1995. The JOBS Evaluation: Early Findings on Program Impacts in Three Sites. New York: Manpower Demonstration Research Corporation.

Friedlander, Daniel. 1988. Subgroup Impacts and Performance Indicators for Selected Welfare Employment Programs. New York: Manpower Demonstration Research Corporation.

Friedlander, Daniel, and Gary Burtless. 1995. Five Years After: The Long-Term Effects of Welfare-toWork Programs. New York: Russell Sage Foundation.

Garfinkel, Irwin, Charles F. Manski, and Charles Michalopoulos. 1992. "Micro Experiments and Macro Effects." In Charles F. Manski and Irwin Garfinkel, eds., Evaluating Welfare Training Programs, chap. 6. Cambridge: Harvard University Press.

Greenberg, David, Robert H. Meyer, and Michael Wiseman. 1993. "Prying the Lid from the Black Box: Plotting Evaluation Strategy for Welfare Employment and Training Programs." Madison: University of Wisconsin, Institute for Research on Poverty.

Gueron, Judith M., and Edward Pauly, with Cameran M. Lougy. 1991. From Welfare to Work. New York: Russell Sage Foundation.

Hagen, Jan L., and Irene Lurie. 1994. Implementing JOBS: Progress and Promise. Albany: State University of New York at Albany, Rockefeller Institute of Government. 
Jencks, Christopher, and Paul E. Peterson, eds. 1991. The Urban Underclass. Washington, D.C.: Brookings Institution.

Katz, Michael B. 1986. In the Shadow of the Poorhouse: A Social History of Welfare in America. New York: Basic Books.

Manski, Charles F., and Irwin Garfinkel, eds. 1992. Evaluating Welfare and Training Programs. Cambridge: Harvard University Press.

Marcotte, John. 1994. "Can Administrative Data Kept by States Be Used to Study the Duration of Program Participation?" Washington, D.C.: Urban Institute.

Mead, Lawrence M. 1986. Beyond Entitlement: The Social Obligations of Citizenship. New York: Free Press.

Mead, Lawrence M. 1988. "The Potential for Work Enforcement: A Study of WIN." Journal of Policy Analysis and Management 7: 264-88.

Mead, Lawrence M. 1992. The New Politics of Poverty: The Nonworking Poor in America. New York: Basic Books.

Mead, Lawrence M. 1994. "Poverty: How Little We Know.” Social Service Review 68: 322-50.

Mead, Lawrence M. 1995. "The New Paternalism in Action: Welfare Reform in Wisconsin." Milwaukee: Wisconsin Policy Research Institute.

Mead, Lawrence M. 1996. "The Decline of Welfare in Wisconsin.” Milwaukee: Wisconsin Policy Research Institute.

Mead, Lawrence M. Forthcoming. “Are Welfare Employment Programs Effective?” In Jonathan Crane, ed., Effective Social Programs. New York: Russell Sage Foundation.

Mitchell, John J., Mark L. Chadwin, and Demetra S. Nightingale. 1980. Implementing WelfareEmployment Programs: An Institutional Analysis of the Work Incentive (WIN) Program. Washington, D.C.: U.S. Government Printing Office.

Moffitt, Robert. 1992a. "Evaluation Methods for Program Entry Effects.” In Charles F. Manski and Irwin Garfinkel, eds., Evaluating Welfare Training Programs. Cambridge: Harvard University Press.

Moffitt, Robert. 1992b. "Incentive Effects of the U.S. Welfare System: A Review." Journal of Economic Literature 30: 1-61.

Moffitt, Robert A. 1996. "The Effect of Employment and Training Programs on Entry and Exit from the Welfare Caseload." Journal of Policy Analysis and Management 15: 32-50.

Nathan, Richard P. 1993. Turning Promises Into Performance: The Management Challenge of Implementing Workfare. New York: Columbia University Press. 
Noble, Kenneth B. 1996. "Welfare Revamp Halted in Capital, Proceeds Anyway." New York Times, March 10, pp. 1, 20.

Norris, Donald F., and Lyke Thompson, eds. 1995. The Politics of Welfare Reform. Thousand Oaks, Calif.: Sage.

Pawasarat, John, and Lois M. Quinn. 1993. "Wisconsin Welfare Employment Experiments: An Evaluation of the WEJT and CWEP Programs." Milwaukee: University of Wisconsin-Milwaukee, Employment and Training Institute.

Plotnick, Robert D. 1990. "Welfare and Out-of-Wedlock Childbearing: Evidence from the 1980s." Journal of Marriage and the Family 52: 735-46.

Preston, Jennifer. 1996. "Job Trainees Support Whitman on Welfare.” New York Times, February 6, p. B6.

Riccio, James, Daniel Friedlander, and Stephen Freedman. 1994. GAIN: Benefits, Costs, and ThreeYear Impacts of a Welfare-to-Work Program. New York: Manpower Demonstration Research Corporation.

U.S. House of Representatives, Committee on Ways and Means. Overview of Entitlement Programs: 1994 Green Book. Washington, D.C.: U.S. Government Printing Office.

Wiseman, Michael. 1993. "Welfare Reform in the States: The Bush Legacy." Focus 15: 18-36.

Wiseman, Michael. Forthcoming. "State Strategies for Welfare Reform: The Wisconsin Story." Journal of Policy Analysis and Management.

Wiseman, Michael, ed. 1991. "Research and Policy: A Symposium on the Family Support Act of 1988." Journal of Policy Analysis and Management 10: 588-666. 